\title{
Effect of Glucocorticoid Therapy on Glucocorticoid Receptors in Children with Autoimmune Diseases
}

\author{
JUDIT ANDREAE, ROBERT TRIPMACHER, RENITA WELTRICH, WOLFGANG ROHDE, \\ ROLF KEITZER, ULRICH WAHN, KARL PAUL, AND FRANK BUTTGEREIT
}

Department of Paediatric Immunology and Pneumology [J.A., R.K., K.P., U.W.], Charité Campus Virchow, University Hospital of Humboldt University, 13353 Berlin, Germany; and Department of Rheumatology and Clinical Immunology [R.T., F.B.], and Institute of Experimental Endocrinology [R.W., W.R.], Charité Campus Mitte, University Hospital of Humboldt University, 10117 Berlin, Germany.

\begin{abstract}
Low-dose glucocorticoids (GC) achieve their action completely by classical genomic effects, mediated by the glucocorticoid receptor (GCR). In high doses of GC, nongenomic effects have also been found, but it is still unclear to what extent they contribute to a beneficial outcome. In this study, we present a determination of the number of lymphocyte GCR sites and the binding affinity in healthy children and children with autoimmune diseases. We further assess the effect of GC administration, especially of high-dose pulse therapy on the number of binding sites. The number of GCR sites per cell was analyzed with $\left[{ }^{3} \mathrm{H}\right]$-dexamethasone radioligand binding assay and binding affinity ( $\mathrm{Kd}$ given in $\mathrm{nM}$ ) in peripheral blood mononuclear cells isolated from 48 healthy children and 35 patients. The patients were divided into three groups based on GC treatment: $0 \mathrm{mg} / \mathrm{kg}$ (group 1), 0.01-0.3 mg/kg orally (group 2), and $10-15 \mathrm{mg} / \mathrm{kg}$ i.v. pulse therapy (group 3) of prednisolone equivalent per day. Gender- and age-independent normal values of $4338 \pm 1687$ sites/lymphocytes and $\mathrm{Kd} 6.7 \pm 2.2 \mathrm{nM}$ were found. At $3463 \pm$
\end{abstract}

\section{ABSTRACT}

1574 , the number of receptor sites in patients without GC (group 1) was significantly lower than that of healthy volunteers $(p<$ $0.05)$. In patients receiving $\mathrm{GC}$ treatment, this value was reduced to $2952 \pm 512$ (group 2). Significant down-regulation to a minimum of $479 \pm 168$ (group 3 ) was found after pulse therapy compared with untreated patients $(p<0.01)$. In pulse therapy, $\mathrm{GC}$ lead to a fast and dramatic receptor down-regulation. We suppose that the increase in therapeutic success of pulse-therapy may partly be mediated through additional nongenomic effects.

(Pediatr Res 49: 130-135, 2001)
GCR, glucocorticoid receptors
GC, glucocorticoids
Kd, dissociation constant of $\left[{ }^{3} \mathrm{H}\right]$ dexamethasone
PBMC, peripheral blood mononuclear cells
MP, methylprednisolone

GC are potent immunosuppressive and anti-inflammatory drugs. Since 1949, they have been used therapeutically in immunologically mediated diseases. Buttgereit et al. have recently published a new modular concept to describe pharmacotherapy with GC (1). It is based on the hypothesis that these agents have both genomic and nongenomic effects. Very low doses of GC produce exclusively genomic effects, mediated by the nuclear GCR. With higher doses, additional nongenomic effects occur that are considered to be mediated by membranebound receptors (specific nongenomic effects) and/or direct physicochemical interaction with cell membranes (nonspecific

Received March 8, 2000; accepted July 13, 2000.

Correspondence and reprint requests: Frank Buttgereit, M.D., Department of Rheumatology and Clinical Immunology, Charité Campus Mitte, University Hospital of Humboldt University, Schumannstrasse 20/21, 10117 Berlin, Germany.

This study was supported by grant Bu 1015/1-1 from the Deutsche Forschungsgemeinschaft (DFG). nongenomic effects). It is still unclear whether these effects add to a beneficial clinical outcome.

Cortisone is known to have the strongest influence on the number of GCR in lymphocytes. This GCR is an intracellular 94-kD protein, which belongs to the superfamily of nuclear hormone receptors $(2,3)$. The receptor protein has two isoforms: GCR $\alpha$, which mediates the hormonal effects, and $\operatorname{GCR} \beta$, which is incapable of binding to the hormone and acts as the antagonist of $\mathrm{GCR} \alpha$ (4).

Normal ranges of GCR in a large collective of healthy children and children with autoimmune diseases are unknown. A few studies with small numbers of patients using different methods have been published (5-7). The aim of this study is to determine comparative data of GCR sites on lymphocytes and binding affinity in healthy children and children with autoimmune diseases under different treatment regimens. Results show for the first time in children the dose-dependent down- 
regulation of GCR content as well as the binding affinity of PBMC after GC administration. We have studied especially the influence of i.v high-dose MP pulse therapy on the GCR density and the fast and dramatic down-regulation of receptors directly after therapy. Therefore, we assume the possible effect of nongenomic action of GC with these very high concentrations.

\section{METHODS}

Ethics. The study was approved by the local ethics committee. Before collecting blood samples, informed consent of parents and patients or volunteers was obtained.

Control group of healthy children. The control group consisted of 48 healthy children and adolescents aged 5-17 y, 28 girls (median $12 \mathrm{y}$ ) and 20 boys (median $10 \mathrm{y}$ ), who were admitted to hospital for an elective operation. All of them had negative signs of infection and no medical history of GC therapy. The blood samples were obtained between 0700 and $0800 \mathrm{~h}$. Laboratory studies included peripheral leukocyte and differential counts, C-reactive protein, plasma cortisol, and GCR analysis.

Patients. In total, 35 children and adolescents with autoimmune diseases ( 19 girls aged $6-16 \mathrm{y}$, median $12 \mathrm{y}$, and 16 boys aged $6-17 \mathrm{y}$, median $13 \mathrm{y}$ ) were investigated. All children were consecutive patients seen in our pediatric outpatient clinic or were admitted to the pediatric rheumatologic and respiratory diseases unit with the following autoimmune diseases:

- Juvenile chronic arthritis (JCA). JCA was diagnosed in 23 children using the criteria of the European League Against Rheumatism (8) (3 systemic JCA, 5 RF-negative polyarthritis, 4 oligoarthritis I, 5 oligoarthritis II, 3 psoriatic arthritis, 3 spondylarthropathy).

- Systemic lupus erythematodes (SLE). Three patients met the revised criteria for SLE (9).

- Other autoimmune diseases (OAD): 2 polymyositis (10); 2 Behçet's syndrome (11); 1 microscopic panarteritis (12); 1 recurrent uveitis (13); 1 neonatal onset of multisystemic inflammatory disease (NOMID) (14), 1 familial Mediterranean fever (15); 1 alveolitis (16).

Blood samples were obtained between 0700 and $0800 \mathrm{~h}$ in all patients and analyzed for erythrocyte sedimentation rate, C-reactive protein, white blood count and differential counts, plasma cortisol, and GCR analysis.

We reported on a total of 48 measurements of GCR and Kd within the three groups divided on the basis of GC dose. These measurements have been obtained on various occasions from the 35 patients classified according to the above-mentioned diagnostic categories (Table 1).

Criteria for starting, restarting, or increasing GC was active disease.

Sixteen patients were receiving GC; of these, five received a high-dose 3-d course of i.v. MP for the first time during these evaluations. The five patients on the high-dose MP course had GCR analysis both before and the day after therapy, and two patients also had GCR analysis 3 wk after the course of MP pulse therapy.

Group formation based on GC treatment. The patients were divided into the following three groups on the basis of GC treatment and dosage:

- Group 1 consisted of 32 patients (15 boys and 17 girls) with rheumatoid diseases with controlled disease activity currently not requiring $\mathrm{GC}$ therapy or patients requiring but not yet treated with GC.

- Group 2 consisted of 11 patients (4 boys and 7 girls) who had a low-dose daily GC therapy of $0.01-0.3 \mathrm{mg} / \mathrm{kg}$ body weight per day. Some patients received GC therapy because of high disease activity, others as long-term therapy to control disease activity.

- Group 3 consisted of 5 patients (2 boys and 3 girls) with acute and severe disease activity, who received for the first time a 3-d course of MP at a dose of $10-15 \mathrm{mg} / \mathrm{kg} / \mathrm{d}$ i.v. over $2-3 \mathrm{~h}$.

Preparation of PBMC. After a complete physical examination, blood samples were taken for routine and laboratory research analysis. Peripheral blood was collected in heparinized syringes and PBMC were isolated by density centrifugation using the Ficoll-Hypaque technique. Specifically, a sample of $15-20 \mathrm{~mL}$ of blood was withdrawn into heparinized tubes. In LeukoSep ${ }^{\circledR}$ tubes with a porous filter disc (Esquire, Zurich, Switzerland), the blood was diluted 2-fold with modified Hanks' balanced salt solution (HBSS pH 7.4; Sigma Chemical Co., St. Louis, MO, U.S.A.) and layered over Ficoll-Hypaque. Density centrifugation was performed at $400 \mathrm{~g}$ for $20 \mathrm{~min}$. The PBMC-enriched interphase was isolated and diluted with 30 $\mathrm{mL}$ HBSS buffer. The cells were incubated for $40 \mathrm{~min}$ at $37^{\circ} \mathrm{C}$ in a shaking bath. This procedure is usually used to remove residual exogenous and endogenous cortisol completely (7, 17-20). Centrifugation was then performed at $400 \mathrm{~g}$ for $8 \mathrm{~min}$. The cell pellet was washed with $35 \mathrm{~mL}$ of HBSS buffer and the final pellet was resuspended in $3 \mathrm{~mL}$ HBSS buffer. The PBMC

Table 1. Distribution of patients according to categories and GC groups

\begin{tabular}{|c|c|c|c|c|c|c|c|c|}
\hline \multirow[b]{2}{*}{ Diagnoses } & \multicolumn{2}{|c|}{$\begin{array}{c}\text { JCA } \\
(n=23)\end{array}$} & \multicolumn{2}{|c|}{$\begin{array}{c}\text { SLE } \\
(n=3)\end{array}$} & \multicolumn{2}{|c|}{$\begin{array}{c}\text { OAD } \\
(n=9)\end{array}$} & \multicolumn{2}{|c|}{$\begin{array}{c}\text { Total } \\
(n=35) \text { (patients) }\end{array}$} \\
\hline & $n_{\mathrm{p}}$ & $m$ & $n_{\mathrm{p}}$ & $m$ & $n_{\mathrm{p}}$ & $m$ & $n_{\mathrm{p}}$ & $m$ \\
\hline Group 2 & 4 & 5 & 2 & 2 & 4 & 4 & 10 & 11 \\
\hline Group 3 & 0 & 0 & 0 & 0 & 5 & 5 & 5 & 5 \\
\hline $\begin{array}{l}\text { Total }(n=48) \\
\quad(\text { GCR analysis })\end{array}$ & 24 & 26 & 4 & 4 & 15 & 18 & 43 & 48 \\
\hline
\end{tabular}

$n$, number of patients; $m$, number of GCR measurements and Kd. 
suspension consisted of lymphocytes and 3\%-15\% monocytes, as determined by fluorescence-activated cell sorter analysis. Trypan blue staining revealed more than $95 \%$ viable cells.

Determination of receptor density and affinity. Established $\left[{ }^{3} \mathrm{H}\right]$ dexamethasone radioligand binding assay and Scatchard analysis were used as described $(7,17-21)$ to determine the number of GCR sites per cell and receptor binding affinity (Kd). In brief, following PBMC preparation as described above, we added to $300 \mu \mathrm{L}$ of cell suspension (containing about $2 \times 10^{6}$ PBMC; a Coulter counter was used in each experiment to determine exact cell numbers), $200 \mu \mathrm{L}$ of $\left[{ }^{3} \mathrm{H}\right]$ labeled dexamethasone $\left(6,7\left[{ }^{3} \mathrm{H}\right]\right.$; specific activity $40-60 \mathrm{Ci} /$ mmol; DuPont De Nemours, Brussels, Belgium) diluted in the same HBSS medium. Four concentrations of tritiumdexamethasone $(2.5,5,10,20 \mathrm{nM})$ were used to achieve a complete binding curve. Identical aliquots were incubated in the presence of a 1000-fold excess of unlabeled dexamethasone to determine nonspecific binding.

Incubation of all aliquots was performed at $37^{\circ} \mathrm{C}$ for $40 \mathrm{~min}$ with continuous shaking and then stopped by adding $2 \mathrm{~mL}$ ice-cold $\mathrm{MgCl}_{2}$ solution. Samples were centrifuged at $800 \mathrm{~g}$ for $2 \mathrm{~min}$ and washed three times with $800 \mu \mathrm{L}$ of PBS at $4^{\circ} \mathrm{C}$. The final pellet was resuspended in $1.6 \mathrm{~mL}$ of isotonic $\mathrm{NaCl}$ solution and transferred into $6 \mathrm{~mL}$ of liquid scintillation cocktail (Serva, Heidelberg, Germany). All incubations were performed in duplicate. Radioactivity was measured for $3 \mathrm{~min}$ in a scintillation counter (model Wallac 1410, Wallac Oy, Turku, Finland). The number of GCR sites per cell was calculated by the Scatchard method (21), using computer-assisted linear regression.

Plasma cortisol. Plasma cortisol levels were estimated with a commercial RIA (Immunotech-Coulter, Marseille, France).

The assay cross-reacted with $6 \alpha$-MP at $0.27 \%$, with prednisone at $<0.1 \%$, and with prednisolone at $6 \%$. The intra-and interassay coefficients of variation were between $3.1 \%$ and $5.8 \%$ and $5.3 \%$ and $9.2 \%$, respectively, for values between 36 and $740 \mathrm{nmol} / \mathrm{L}$.

Statistical methods. All results for number of GCR are expressed as geometrical mean/SD. Dissociation constant $(\mathrm{Kd})$ and plasma cortisol levels are expressed as mean/SD. Results between the groups were compared using the Mann-Whitney test. Probability values of $<0.05$ were considered to be statistically significant.

\section{RESULTS}

GCR content and dissociation constant in healthy controls. In 48 healthy children ( 20 boys and 28 girls, aged 5 to $17 \mathrm{y}$, median $11 \mathrm{y}$ ), the number of GCR was $4338 \pm 1687$ sites/ lymphocyte and the mean binding affinity showed a Kd of 6.7 $\pm 2.2 \mathrm{nM}$ (Fig. 1). There was no statistical difference between males and females and no correlation with age was found.

GCR content and $K d$ in patients with autoimmunologicmediated diseases. In group 1, the number of GCR and $\mathrm{Kd}$ in 32 patients ( 15 boys and 17 girls, aged 6 to $16 \mathrm{y}$, median $12 \mathrm{y}$ ) not receiving steroid therapy was significantly lower than in healthy children $(p<0.02)$. The geometrical mean was 3463 \pm 1574 sites/lymphocyte for GCR. Dissociation constant Kd was lower, with $5.2 \pm 2.1$ resulting in higher binding affinity than in healthy children (Fig. 1).

In group 2, 11 patients ( 4 boys, 7 girls, median 13 y) who had low-dose oral GC therapy (0.01- $0.3 \mathrm{mg}$ prednisolone $/ \mathrm{kg} /$ d), binding sites of GCR were lower than in patients without GC treatment. The geometrical mean of $2952 \pm 512$ sites/ lymphocyte and mean values for $\mathrm{Kd}$ of $4.9 \pm 1.6 \mathrm{nM}$ were determined, but significance was not reached compared with untreated patients (see Fig. 1).

In group 3, five patients ( 2 boys and 3 girls, median 12 y) were treated with MP pulse therapy over a 3-d course, with i.v. doses of $10-15 \mathrm{mg} / \mathrm{kg} / \mathrm{d}$. Baseline values of GCR and $\mathrm{Kd}$ before treatment were comparable with those of patients in group 2, because three of the patients had prior oral low-dose GC therapy. Measurement on the day after pulse therapy determined significant reduction to values of $479 \pm 168$ sites/ lymphocyte - only one-sixth of the baseline values. In two patients, the binding assay was performed 3 wk after pulse therapy and showed a return to normal values with 3373 and 3584 sites/lymphocyte, respectively, comparable with other patient groups (Fig. 2).

There were no differences between the different diseases. Within the patient groups, Kd did not differ significantly. Other publications also found no difference in quantity of GCR in relation to age or gender $(17,21)$.

Plasma cortisol levels. Healthy children in the control group had plasma cortisol levels within normal limits (140-665 $\mathrm{nmol} / \mathrm{L}$ ). No correlations with gender and age were found.

Children in group 1 (patients without GC therapy) had plasma cortisol levels toward the lower end of the normal range, with $290 \pm 144 \mathrm{nmol} / \mathrm{L}$.

In group 2 ( $\mathrm{GC}$ treatment of $0.01-0.3 \mathrm{mg} / \mathrm{kg} / \mathrm{d})$, some patients had suppressed plasma cortisol levels. Five patients had values below $140 \mathrm{nmol} / \mathrm{L}$, with $99.6 \pm 15.7 \mathrm{nmol} / \mathrm{L}$, but the remaining six patients had plasma cortisol levels within normal limits, with $222 \pm 78.8 \mathrm{nmol} / \mathrm{L}$.

Children receiving pulse therapy (group 3) had strongly suppressed plasma cortisol levels of $47 \pm 35 \mathrm{nmol} / \mathrm{L}$, which normalized $3 \mathrm{wk}$ after therapy (Table 2).

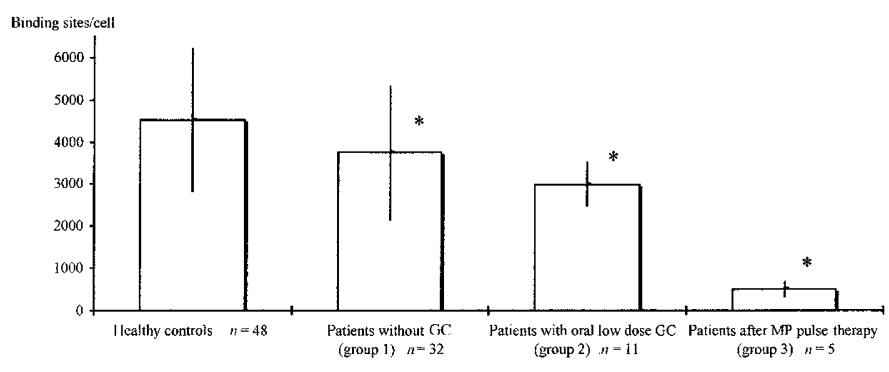

Figure 1. GCR content in healthy children and children with autoimmune diseases. In a large collective of 48 healthy boys and girls, GCR number and dissociation constant were determined by radioligand binding assay and Scatchard analysis. They were compared with children with autoimmune diseases. Patients had significantly lower GCR numbers than healthy controls. Patients with oral low-dose GC treatment $(0.01-0.3 \mathrm{mg} / \mathrm{kg} / \mathrm{d})$ showed fewer receptor numbers than patients without treatment (NS). After i.v. MP pulse therapy $(10-15 \mathrm{mg} / \mathrm{kg} / \mathrm{d}$ for $3 \mathrm{~d})$, a fast and dramatic down-regulation of receptor content was found in five patients. ${ }^{*} p<0.02$ compared with healthy children. 


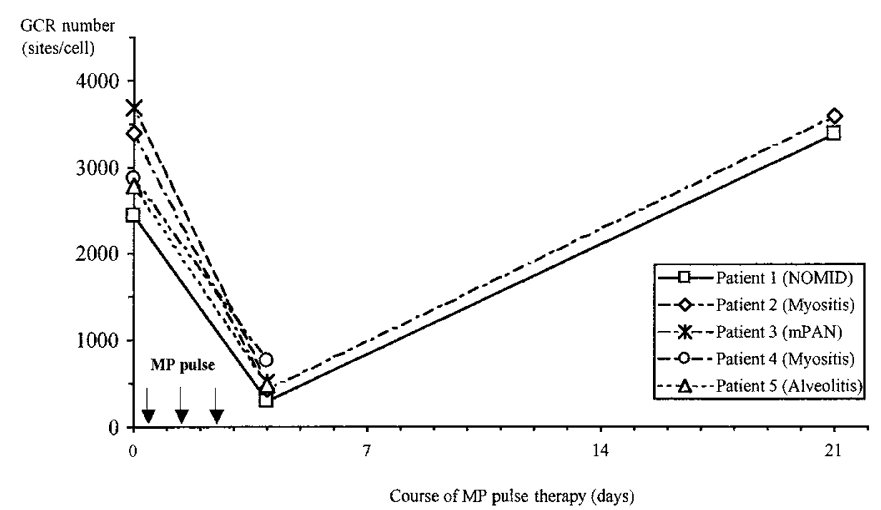

Figure 2. Number of GCR in patients before and after MP pulse therapy $(10-15 \mathrm{mg} / \mathrm{kg} / \mathrm{d})$. Five patients with severe outbreaks of their autoimmune diseases were successfully treated with MP pulse therapy. The number of GCR were down-regulated to only one-sixth of baseline values directly after pulse therapy, but measurements of two patients showed a return to normal values after $3 \mathrm{wk}$.

Table 2. GCR content, $K d$, and plasma cortisol levels

\begin{tabular}{|c|c|c|c|}
\hline & $\begin{array}{l}\text { Number of GCR } \\
\text { (sites/lymphocyte: } \\
\text { geom. mean/SD) }\end{array}$ & $\begin{array}{c}\text { Dissociation } \\
\text { constant } \\
(\mathrm{Kd} \text { in } \mathrm{nM} \\
\text { mean/SD) }\end{array}$ & $\begin{array}{l}\text { Plasma cortisol } \\
\text { level }(\mathrm{nmol} / \mathrm{l}: \\
\text { mean } / \mathrm{SD})^{*}\end{array}$ \\
\hline Healthy controls $(n=48)$ & $4338 \pm 1780$ & $6.7 \pm 2.2$ & $382 \pm 184$ \\
\hline Girls $(n=28)$ & $4292 \pm 1789$ & $6.2 \pm 2.2$ & $375 \pm 206$ \\
\hline Boys $(n=20)$ & $4404 \pm 1811$ & $7.3 \pm 2.0$ & $392 \pm 153$ \\
\hline $\begin{array}{l}\text { Group 1: Patients with no } \\
\text { GC }(n=32)\end{array}$ & $3463 \pm 1574$ & $5.2 \pm 2.1$ & $290 \pm 144$ \\
\hline Girls $(n=17)$ & $3229 \pm 1211$ & $5.5 \pm 2.0$ & $278 \pm 149$ \\
\hline Boys $(n=15)$ & $3748 \pm 1885$ & $4.9 \pm 2.2$ & $236 \pm 91$ \\
\hline $\begin{array}{l}\text { Group 2: Patients with oral } \\
\text { GC }(n=11) \\
(0.01-0.3 \mathrm{mg} / \mathrm{kg} / \mathrm{d})\end{array}$ & $2952 \pm 512$ & $4.9 \pm 1.6$ & $166 \pm 85$ \\
\hline Girls $(n=6)$ & $2852 \pm 563$ & $4.9 \pm 1.5$ & $161 \pm 58$ \\
\hline Boys $(n=5)$ & $3086 \pm 427$ & $4.7 \pm 1.9$ & $180 \pm 155$ \\
\hline $\begin{array}{l}\text { Group 3: Patients before } \\
\text { pulse therapy }(n=5)\end{array}$ & $3004 \pm 500$ & $5.9 \pm 3.1$ & $403 \pm 117$ \\
\hline $\begin{array}{c}\text { Patients } 1 \mathrm{~d} \text { after pulse } \\
\text { therapy }(n=5) \\
(10-15 \mathrm{mg} / \mathrm{kg} / \mathrm{d})\end{array}$ & $479 \pm 168$ & $4.4 \pm 2.1$ & $47 \pm 35$ \\
\hline Patients 3 wk after & 3373 & 6.0 & 120 \\
\hline pulse therapy $(n=2)$ & 3584 & 3.1 & 360 \\
\hline
\end{tabular}

* Normal values: $140-665 \mathrm{nmol} / \mathrm{L}$.

\section{DISCUSSION}

In this study, we present for the first time comparative normal values of GCR and the binding affinity of PBMC in a large collective of healthy children. In this group, we determined $4338 \pm 1687$ GCR sites per lymphocyte with a Kd of $6.7 \pm 2.2 \mathrm{nM}$. No correlations with gender or age were found. Of special interest is that numbers of GCR in the children below 9 y of age and in the older subjects were similar. This suggests that no significant change in GCR content occurs with the onset of puberty.

Early reports of hematological malignancies provide the first data about GCR content in healthy adults and children. In the various reports, binding sites of GCR in blood lymphocytes were found to be in a range from 3000 to 7000 sites per cell with a Kd of around $10^{-8} \mathrm{M}(22)$. Tanaka et al. (19) described the effects of age, gender, and season on GCR in normal leukocytes of 145 healthy subjects aged $18-78 \mathrm{y}$. They did not find a difference of receptor number related to season, circadian rhythm, plasma cortisol, or gender, but reported a decrease of GCR in healthy volunteers over the age of 20. Schlaghecke et al. (23) determined GCR in 100 healthy adult men and women, respectively, but did not find a correlation with gender or season. However, they found a significant difference in the circadian rhythm of GCR, with higher numbers at $2300 \mathrm{~h}$. They could not confirm an age-related decrease of GCR and the binding affinity did not differ between the groups. They further compared healthy adults and patients with rheumatoid arthritis concerning the difference in GCR content and binding affinity. An important finding was that the number of GCR was significantly higher in healthy volunteers (5619 \pm 1369 binding sites per lymphocyte) than in patients with rheumatoid arthritis $(2159 \pm 492)$ who were not being treated with GC. We also measured significantly lower receptors in the group of patients with autoimmune diseases without current GC treatment (group 1), compared with healthy children. We measured GCR in group 1 at $3463 \pm 1574$ sites per lymphocyte and $\mathrm{Kd}$ was $5.2 \pm 2.1 \mathrm{nM}$. It is interesting that two-thirds of these patients had a juvenile chronic arthritis as underlying autoimmune disease, which is similar to Schlaghecke's group of patients with rheumatoid arthritis. In contrast, Sanden et al. (17) very recently determined significantly more GCR in adult patients with autoimmune diseases, compared with healthy adult volunteers. However, this group consisted predominantly of patients with SLE, and only $20 \%$ had rheumatoid arthritis, which could explain the different findings.

Many authors have observed down-regulation of GCR after GC administration. Schlechte et al. (1982) and Shipman et al. (1983) showed a decrease of receptor number in healthy volunteers after GC administration. The down-regulation was rapid and return of receptor number to baseline required up to 2.5 wk $(24,25)$.

Several mechanisms of GCR down-regulation have been reported. It is well known that the most important factor in down-regulation of GCR is the modulation of GC themselves. One explanation for this negative feedback is the protection of tissue from possible damage due to excessive and extended GC action (26). Further, tight regulation of activity of the GCR is suggested because of the wide spectrum of positive and negative gene expression by the GCR. There are transcriptional, posttranscriptional, and posttranslational effects described as mechanisms of down-regulation. On the transcriptional level, GC decrease GCR mRNA significantly after $2-3 \mathrm{~h}$. This has been observed in all cells and tissues that undergo downregulation of GCR protein. Reduction of the GCR protein level itself requires at least $12-24 \mathrm{~h}$ after the start of therapy (4, 26-33). Activated GCR have also been shown to bind to sites of coding DNA and/or mRNA, rather than within the GCR promoter, which lacks consensus glucocorticoid responsive element sites (34-36). The result is down-regulation by inhibition of transcription and/or by reduction of mRNA stability and translatability (37). An additional mechanism of downregulation is the reduction of GCR protein half-life in the presence of GC (38). 
In the present study, we found GCR down-regulation in patients who received oral low-dose GC treatment up to 0.3 $\mathrm{mg} / \mathrm{kg} / \mathrm{d}$ (group 2), but this did not reach significance. Griese did not find a significant difference between only a small number of healthy and asthmatic children; but when a short course of prednisolone therapy was administered in the asthmatics, significant reduction in GCR number was seen (5). Hampl et al. could not determine any significant difference in GCR content between healthy children and children with systemic diseases under long-term GC therapy with doses of 0.04-1.4 mg/kg prednisolone per day (6), but they used a different method. In our laboratory, Sanden et al. reported for the first time dose dependency in GCR down-regulation. It was shown that GC administration from doses of $0.25-1 \mathrm{mg} / \mathrm{kg} / \mathrm{d}$ results in significant reduction of GCR in lymphocytes in vivo. Doses $>1 \mathrm{mg} / \mathrm{kg} / \mathrm{d}$, usually achieved in pulse therapy in adults, resulted in even greater down-regulation of the GCR. Nevertheless, very low doses of oral prednisolone (up to $0.25 \mathrm{mg} /$ $\mathrm{kg} / \mathrm{d}$ ) did not lead to a significant reduction of binding sites (17). This is similar to our findings that the patients of group 2, taking very low oral prednisolone doses (up to $0.3 \mathrm{mg} / \mathrm{kg} / \mathrm{d}$ ), showed a (nonsignificant) down-regulation compared with patients with no steroid treatment. It seems that down-regulation of GCR requires doses above $0.25 \mathrm{mg} / \mathrm{kg} / \mathrm{d}$. The exact doseequivalent of prednisolone, where receptor reduction starts, still has to be established.

GC are important anti-inflammatory and immunosuppressive drugs with three distinct effects: genomic, specific nongenomic, and unspecific nongenomic. It is widely appreciated that GC act mostly via receptor-mediated effects (39) (classical genomic effects). For these genomic effects, GC bind to the ubiquitously expressed cytosolic GCR. The activated steroidreceptor complex is then translocated to the nucleus, where the synthesis of important regulating proteins, e.g. lipocortin-1, an inhibitor of phospholipase $\mathrm{A}_{2}$, is initiated. The steroid-receptor complex also interacts with transcription factors (activatingprotein- 1 and nuclear factor $-\kappa \mathrm{B}$ ), resulting in decreased synthesis of certain proteins, such as proinflammatory cytokines. These genomic actions of GC are observed at any therapeutic concentration, but occur not earlier than $30 \mathrm{~min}$ after receptor binding (1), whereas nongenomic effects have been shown to occur only at high doses (40). From in vitro experiments it is suggested that at doses below $250 \mathrm{mg}$ prednisolone equivalent per day, nongenomic effects are of minor concern $(41,42)$. Increasing the dose of $\mathrm{GC}$ leads to additional nongenomicmediated effects (1). Nongenomic effects occur rapidly (within seconds to a few minutes) and result mainly from interaction with cell membranes. It is believed that specific nongenomic actions are mediated by steroid-selective membrane-bound receptors, which leads to a second messenger cascade. Nonspecific nongenomic actions of GC are direct physicochemical effects on cellular membranes (43). In therapeutically relevant concentrations, MP instantaneously inhibits $\mathrm{Ca}^{2+}$ and $\mathrm{Na}^{+}$ ions cycling across the membranes and decreases intracellular free calcium concentrations, but has little effect on protein synthesis (44). Further effects are a decreased phospholipid turnover in the cell membranes and a decreased production of free radicals (43). These direct effects are suggested to be mediated by direct actions on biologic membranes and are supposed to interfere with activation and maintenance of immune cells. Therefore, we believe that with the administration of high doses of GC we take additional advantage of the nongenomic effects, which then may mediate to a better result in quickly combating the acute and intense immune responses.

Severe autoimmune disorders in childhood often require prolonged treatment with GC. The therapy shows the same side effects as in adults with one major additional problem: it also inhibits linear growth. MP pulse therapy is a very effective treatment in autoimmune-mediated diseases (45-48), with relatively mild and transient side effects in children (49) and is also believed not to interfere with linear growth $(50,51)$. This therapy is especially important if rapid and strong control of disease activity is needed.

We studied five patients with different underlying autoimmune diseases, who had an acute and severe outbreak of the disease and consequently underwent MP pulse therapy. Before starting pulse therapy, the baseline number of GCR corresponded to that of patients with low-dose oral GC (group 2). Measurement on the day after the 3-d course of pulse therapy showed that the high concentration of GC produced receptor saturation and led to a rapid and dramatic down-regulation of receptors. These high concentrations of $\mathrm{GC}$ consequently meet only one-sixth of the baseline values of GCR. We have observed that by adhering to the usual interval of 3-4 wk between pulses, the number of GCR do recover from down-regulation, as shown by analysis of two patients. Compared with group 2 (patients receiving low-dose oral GC), the doses of the administered GC in pulse therapy are evidently much higher and result in a dramatic down-regulation of the GCR. The reason for this decrease in binding sites could be that the much higher doses of hormone recruit more GCR and quantitatively more genomic effects are produced, which then lead to a more profound down-regulation. However, it cannot be excluded that the appearance of additional nongenomic effects of $\mathrm{GC}$ at high doses contribute to this down-regulation by as yet unknown mechanisms.

The cause for our findings that children with autoimmune diseases without GC therapy have lower GCR numbers than healthy controls remains unclear. The current understanding of a regulatory degradation of the number of GCR requires GC themselves, which act by the described mechanisms of downregulation. However, in the patients of group 2 we found plasma cortisol levels that were at the lower end of the normal range, with few patients having slightly decreased levels (Table 2). Several authors have described similar findings in adult rheumatoid arthritis patients who have low plasma cortisol levels that are still within the normal limits (52). A potential pathogenetic mechanism in chronic inflammatory disorders could be a hypofunction of the hypothalamic-pituitary-adrenal axis, as several investigators have suggested in patients with rheumatoid arthritis (53).

Therefore, it can only be speculated that either inherent genetic factors or active inflammatory mechanisms lead to a decrease in GCR numbers in children with autoimmune disorders. A possible mechanism could be the increased levels of 
proinflammatory cytokines and/or other inflammatory mediators.

In conclusion, the present study shows that children with autoimmune diseases have lower GCR numbers on PBMC than healthy children. There is no clinical doubt of the therapeutic effectiveness of the treatment with MP pulse therapy, despite the significant subsequent decrease in binding sites for the hormone. We support the hypothesis that the success of pulse therapy may partly be mediated by additional nongenomic effects.

\section{REFERENCES}

1. Buttgereit F, Wehling M, Burmester G-R 1998 A new hypothesis of modular glucocorticoid actions. Arthritis Rheum 41:761-767

2. Evans RM 1988 The steroid and thyroid hormone receptor superfamily. Science 240:889-895

3. Mangelsdorf DJ, Thummel C, Beato M, Herrlich P, Schütz G, Umesono K, Blumberg B, Kastner P, Mark M, Chambon P, Evans RM 1995 The nuclear receptor superfamily: the second decade. Cell 83:835-839

4. Bamberger CM, Schulte HM, Chrousos GP 1996 Molecular determinants of glucocorticoid receptor function and tissue sensitivity to glucocorticoids. Endocr Rev 17:245-261

5. Griese M, Kusenbach G, Lüsebring K, Köster W, Roth B, Reinhardt D 1988 Glucocorticoid receptors in mononuclear blood cells and their correlation to endogenous and exogenous corticoids in healthy and asthmatic children. Eur J Pediatr 147:490-495

6. Hampl R, Lapcik O, Sulkova J, Starka L, Kalvachova B, Dvorakova M, Nemkova D, Hoza J 1994 The effect of long-term GC therapy on GC receptor content and on steroid response to ACTH. Steroid Biochem Mol Biol 48:81-87

7. Sher ER, Leung DY, Surs W, Kam JC, Zieg G, Kamada AK, Szefler SJ 1994 Steroid resistant asthma: cellular mechanism contributing response to glucocorticoid therapy. J Clin Invest 93:33-39

8. Wood PN 1978 Nomenclature and classification of arthritis in children. In: Munthe E (ed) The Care of Rheumatic Children. EULAR, Basel, pp 47-50

9. Tan EM, Cohen AS, Fries JF, Masi AT, McShane DJ, Rothfield NF, Schaller JG, Talal N, Winchester RJ 1982 The 1982 revised criteria for the classification of systemic lupus erythematodes. Arthritis Rheum 25:1277-1281

10. Tanimoto K, Nakano K, Kano S, Mori S, Ueki H, Nishitani H, Sato T, Kiuchi T, Ohashi Y 1995 Criteria for polymyositis and dermatomyositis. J Rheumatol 22:668674

11. International Study Group for Behçet's disease 1992 Diagnostic criteria. Br J Rheumatol 31:299-308

12. Jennette JC, Falk RJ, Andrassy K, Bacon PA, Churg J, Gross WL, Hagen EC, Hoffman OS, Hunder GG, Kallenberg CGM, McKlusky RT, Sinico RA, Rees AJ, van Es LA, Waldherr R, Wiik A 1994 Nomenclature of systemic vasculitides: proposal of an international consensus conference. Arthritis Rheum 37:187-192

13. Bloch-Michel E, Nussblatt RB 1987 International Uveitis study group recommendations for the evaluation of intraocular inflammatory disease. Am J Ophthalmol $103: 234-235$

14. Prieur AM, Lovell D 1990 The chronic, infantile, neurological, cutaneous and articular syndrome (CINCA Europe, NOMID USA). In: Woo P, White PH, Ansell BM (eds) Paediatric Rheumatology Update. Oxford Press, Oxford pp 147-160

15. Heller H, Sohar E, Sheri L 1958 Familial Mediterranean fever. Arch Intern Med 102:540-546

16. Lynch DA, Hay T, Newell Jr JD, Divgi VD, Fan LL 1999 Pediatric diffuse lung disease: diagnosis and classification using high-resolution CT. Am J Roentgenol 173:713-718

17. Sanden S, Tripmacher R, Weltrich R, Rohde W, Hiepe F, Burmester GR, Buttgereit F 2000 Glucocorticoid dose dependent downregulation of glucocorticoid receptors in patients with rheumatic diseases. J Rheumatol 27:1265-1270

18. Tanaka H, Akama H, Ichikawa Y, Homma M, Oshima H 1991 Glucocorticoid receptors in normal leukocytes: effects of age, gender, season, and plasma cortisol concentrations. Clin Chem 37:1715-1719

19. Shimada T, Hiwatashi N, Yamazaki H, Kinouchi Y, Toyota T 1997 Relationship between glucocorticoid receptor and response to glucocorticoid therapy in ulcerative colitis. Dis Colon Rectum 40:S54-S58

20. Schlaghecke R, Kornely E, Wollenhaupt J, Specker C 1992 Glucocorticoid receptor in rheumatoid arthritis. Arthritis Rheum 35:740-744

21. Scatchard G 1949 The attractions of protein by small molecules and ions. Ann N Y Acad Sci 51:660-672

22. Homo-Delarche F 1984 Glucocorticoid receptors and steroid sensitivity in normal and neoplastic human lymphoid tissues: a review. Cancer Res 44:431-437
23. Schlaghecke R 1992 Glukokortikoidrezeptoren-Parameter der zellulären Wirkung endogener und synthetischer Glukokortikoide im menschlichen Organismus. Vieweg, Wiesbaden pp38-71

24. Schlechte JA, Ginsberg BH, Shermann BM 1982 Regulation of the glucocorticoid receptor in human lymphocytes. J Steroid Biochem 16:69-74

25. Shipman GF, Bloomfield CD, Kazimiera J G-P, Munck AU, Smith KA 1983 Glucocorticoids and Lymphocytes. III. Effects of glucocorticoid administration on lymphocyte glucocorticoid receptor. Blood 61:1086-1090

26. Burnstein KL, Cidlowski JA 1992 The down side of glucocorticoid receptor regulation. Mol Cell Endocrinol 83:C1-C8

27. Burnstein KL, Bellingham DL, Jewell CM, Powell-Oliver FE, Cidlowski JA 1991 Autoregulation of glucocorticoid receptor gene expression. Steroids 56:52-58

28. Hoeck W, Rusconi S, Groner B 1989 Down-regulation and phosphorylation of glucocorticoid receptors in cultured cells. J Biol Chem 264:14396-14402

29. Dong Y, Poellinger L, Gustafsson JA, Okret S 1988 Regulation of glucocorticoid receptor expression: evidence for transcriptional and posttranslational mechanisms. Mol Endocrinol 2:1256-1264

30. Barrett TJ, Vig E, Vedeckis WV 1996 Coordinate regulation of glucocorticoid receptor and c-jun gene expression is cell type specific and exhibits differential hormonal sensitivity for down- and up-regulation. Biochemistry 35:9746-9753

31. Knutsson PU, Brönnegard M, Marcus C, Stierna P 1996 Regulation of glucocorticoid receptor mRNA in nasal mucosa by local administration of fluticasone and budenoside. J Allergy Clin Exp Immunol 97:655-661

32. Vachier I, Roux S, Chanez P, Loubatiere J, Terouanne B, Nicolas JC, Godard P 1996 Glucocorticoid induced down-regulation of glucocorticoid receptor mRNA expression in asthma. Clin Exp Immunol 103:311-315

33. Kumar MV, Tindall DJ 1998 Transcriptional regulation of the steroid receptor genes. Prog Nucleic Acid Res Mol Biol 59:289-306

34. Nobukuni Y, Smith CL, Hager GL, Detera-Wadleigh SD 1995 Characterization of the human glucocorticoid receptor promoter. Biochemistry 34:8207-8214

35. Zong J, Ashraf J, Thompson EB 1990 The promoter and first untranslated exon of the human glucocorticoid receptor gene are GC rich but lack consensus glucocorticoid receptor element sites. Mol Cell Biol 10:5580-5585

36. Encio IJ, Detera-Wadleigh SD 1991 The genomic structure of the human glucocorticoid receptor. J Biol Chem 266:7182-7188

37. Burnstein KL, Bellingham DL, Jewell CM, Sar M, Cidlowski JA 1994 Intragenic sequences of the human glucocorticoid receptor complementary DNA mediate hormone-inducible receptor messenger RNA down-regulation through multiple mechanisms. Mol Endocrinol 8:1764-1773

38. McIntyre WR, Samuels HH 1985 Triamcinolone acetonide regulates glucocorticoidreceptor levels by decreasing the half-life of the activated nuclear-receptor form. J Biol Chem 260:418-427

39. Barnes PJ 1998 Anti-inflammatory actions of glucocorticoids: molecular mechanism. Clin Sci 94:557-572

40. Wehling M 1997 Specific, nongenomic actions of steroid hormones. Annu Rev Physiol 59:356-393

41. Buttgereit F, Krauss S, Brandt MD 1997 Methylprednisolone inhibits uptake of $\mathrm{Ca}^{2+}$ and $\mathrm{Na}^{+}$into concanavalin A-stimulated thymocytes. Biochem J 326:329-332

42. Buttgereit F, Grant A, Müller M, Brand D 1994 The effects of methylprednisolone on oxidative phosphorylation in concanavalin-A-stimulated thymocytes: top-down elasticity and control analysis. Eur J Biochem 223:513-519

43. Buttgereit F, Burmester GF, Brand MD 2000 Bioenergetics of immune functions: fundamental and therapeutic aspects. Immunol Today 21:192-199

44. Buttgereit F, Brand MD, Müller M 1993 Effects of methylprednisolone on the energy metabolism of quiescent and concanavalin-A-stimulated thymocytes of the rat. Bioscience Rep 13:41-52

45. Cole BR, Brocklebank JT, Kienstra RA, Kissane RA, Robson AM 1976 Pulse methylprednisolone therapy in the treatment of severe glomerulonephritis. J Pediatr 88:307-314

46. Barron KS, Person DA, Brewer EJ, Beale MG, Robson AM 1982 Pulse methylprednisolone therapy in diffuse proliferative lupus nephritis. J Pediatr 101:137-141

47. Laxer RM, Stein LD, Petty RE 1987 Intravenous pulse methylprednisolone treatment of juvenile dermatomyositis. Arthritis Rheum 30:328-334

48. Shaikov AV, Maximov AA, Speranski AI, Lovell DJ, Giannini EH, Soloveyev SK 1992 Repetitive use of pulse therapy with methylprednisolone and cyclophosphamide in addition to oral methotrexate in children with systemic juvenile rheumatoid arthritis - preliminary results of a long time study. J Rheum 19:612-616

49. Miller JJ 1980 Prolonged use of large intravenous steroid pulses in the rheumatic diseases of children. Pediatrics 65:989-994

50. Paul K, Klettke U, Moldenhauer J, Müller KM, Kleinau I, Magdorf K, Wahn U 1999 Increasing dose of methylprednisolone pulse therapy treats desquamative interstitial pneumonia in a child. Eur Respir J 14:1429-1432

51. Job-Deslandre C, Menkes CJ 1991 Administration of methylprednisolone pulse in chronic arthritis in children. Clin Exp Rheum 9(suppl 6):15-18

52. Harbuz MS, Jessop DS 1999 Is there a defect in cortisol production in rheumatoid arthritis? Rheumatology 38:298-302

53. Masi AT, Chrousos GP 1996 Hypothalamic-pituitary-adrenal-glucocorticoid axis function in rheumatoid arthritis. J Rheumatol 23:577-581 